\title{
Does Motivation Contribute on Health Care Provision?
}

\author{
Elizabeth Landa \\ School of Public Administration and Management \\ Mzumbe University \\ P.o Box 2, Mzumbe, Morogoro, Tanzania
}

Received: April 7, 2018 Accepted: April 27, 2018 Online published: May 13, 2018

doi:10.5296/ijhrs.v8i2.13135

URL: https://doi.org/10.5296/ijhrs.v8i2.13135

\begin{abstract}
This study aimed to examine the contribution of employee motivation on provision of customer care in public health centres, in Morogoro Municipality. Data were collected from four selected public health institutions namely Morogoro General Hospital, Nunge Health Centre, Mafiga Health Centre and Kingolwila Health Centre respectively. The sample of 124 respondents were used, that is; employees and heads of the health centres. Collected data were coded using SPSS, where frequencies, percentages and chi-square were employed. The study identified that career development, training, appreciation, recognition, membership to the Social Security Fund, team work, working condition, paid leave, housing allowances and acting allowance were, the motivation schemes provided to public health employees. However public health workers are motivated by being a member on social security fund, medical cover, supervision, and job security. The result shows that there is significant difference between the employee who are motivated and those who are not motivated with regard to their provision of customer care to patients. The study concludes that most of the employees are not motivated by the existing motivation schemes which consequences lower their ability to provide the appropriate health services. The study recommends that strategies for improving motivation of employee to improve customer care include increase salary, improve working condition, pay housing allowance to all employees, allowance such as leave, overtime should be paid on time, promotion should be made in appropriate time and fair.
\end{abstract}

Keywords: motivation, customer care, public health services, employees

\section{Introduction}

A major issue which appears to affect provision of effective customer care is motivation. Findings by (Leshabar, Eustace, Muhondwa, Naboth \& Mbembati, 2008) and (Songstad, Rekdal, Massay \& Blystad ,2011) show low motivation among employees in the health sector in spite of the number of reforms and motivation schemes that are in place to enhance the 
employees' health services delivery. The number of strikes by health workers such as that of December 2005 and January -February 2012 is also a reflection of low motivation and reflects the need to motivate workers to ensure proper care of sick people. In response to this, the public health sector in Tanzania has been undergoing a number of reforms with an anticipated improvement in the quality of health care. The reforms include the restructuring of the salary scale of government employees and other motivation schemes.

A report by the Minister of Health and Social Welfare (2010) shows that there is low quality of health services provided in public institutions. It states that the key barrier to low quality of health care includes quality of care, availability of essential drugs ,shortage of skilled providers, distance and transport, health care charges, unofficial payments and bribes, as well as governance and accountability.

In additional, improving access, coverage and quality of services depends on most aspects of job motivation including key resources being available; on the ways services are organized and managed, and on incentives influencing providers (WHO, 2011). The study by (Manongi, Marchant \& Bygbjerg, 2007) which focuses on the extent to which employee motivation affects work performance in public sector, found that public servants require better working conditions, benefits and other incentives for them to provide good service.

Despite the fact that there reforms made by the government of the United Republic of Tanzania in health sector, that have been introduced by the government to motivate employees for improving health care provision so as to ensure health customers are well cared; still health care services remain poor and health care providers are even going on strike. A key problem appears to be low motivation of health employees (Leshabar et al., 2008; Songstad et al, 2011). This indicates that health employees are not well motivated or that existing motivation schemes are not sufficient. Hence this study attempts to examine the impact of motivation schemes on customer care in public health services taking Morogoro municipality as case study. The study examined motivation schemes and their influence/impact on the provision of customer care. The central focus was thus to examine the extent to which motivation influences customer care in public health services in Tanzania taking public health centres in Morogoro Municipality.

\section{Method}

The research design adopted for the study is cross sectional. The study was carried out in Morogoro Region because it is among the regions with high rate of dissatisfaction with regard to public service delivery (URT, 2004). Selected public health centres included; Morogoro general hospital, Nunge Clinic, Kingolwila Dispensary and Mafiga Maternity ward.

Multi stage simple random sampling technique was used to draw the sample of the district and health institutions that were involved in the survey. The first sampling stage employed the random sampling techniques to select one district, Morogoro municipality. After selecting the district next stage was to select the public health institutions. The four public health institutions including the regional hospital were purposively selected due to the number of 
patients and kind of public health services provided. From the list of public health institutions in Morogoro municipality; four public health institutions were chosen namely Morogoro referral hospital, Nunge Clinic, Kingolwila Dispensary and Mafiga Maternity ward. The public health centre was selected based on the population of the people it serves (it serves more people). Stratified random sampling were employed to select 120 respondents such as doctors, nursing staff, clinical workers and other administrative and supporting staff.

Data were collected from respondents through questionnaire and the use of semi- structured interview schedule. The interview schedule contains the theme base on the objective of the study which was motivational schemes and their influence on provision of customer care. The quantitative data collected were coded and summarized prior to analysis, by using the Statistical Package for Social Sciences (SPSS). The researcher utilized descriptive statistics, such as frequencies, percentages in data analysis. Qualitative data were analysed using content analysis.

\section{Results and discussion}

\subsection{Existing Schemes of Motivation with Their Respective Extent}

In this section the study aimed to examine the existing schemes of motivation provided to employees in public health institutions and the extent to which employees are motivated by those motivations. Various schemes of motivation available and used by public health institutions in Morogoro municipality were identified. In each of the mentioned motivation scheme, respondents were requested to state the extent to which public health workers are motivated by those motivation schemes.

\section{Career development}

Career development was identified by 59(49.1\%) respondents who were less than half of the respondents. This means that majority of health workers do not feel that they have opportunity to make progress in their work. The studies indicate that health workers take pride and are motivated when they feel they have the opportunity to progress (Elmers, De Gilder \& Haslan ,2004). 38(65.1\%) respondents indicated that they are not motivated by career development in public health institution. The major reason for not being motivated by career development, as noted by one respondent in an interview is that "the government do not give us the opportunity to make progress in our work....since I was employed I didn't receive any opportunity to build my career"

\section{Training}

Majority of the respondents (88 respondents) equals to $(70.8 \%)$ mentioned provision of training as one of the motivation package provided to public health employees; while further findings revealed that only 6(6.8\%) respondents were more motivated by training and $14(15.9 \%)$ respondents were demotivated by the training opportunities provided. The reason given by health workers in in-depth interviews was that training programmes were given to a certain cadre.

The provision of a formal training scheme is important. As Herzberg stated, without training, 
workers will not be able to fulfil their potential. Training can be on-the-job, learning by doing, or off the job, such as studying at a local college. On the job training has costs such as management or supervisor time spent training, and potential reduction in quality of output. Off the job training, means lost production, and disruption, also the newly qualified worker may seek to use his qualifications to seek better employment elsewhere. Training is another area that influences employees' motivation within an organization. Training enables health workers to take on more demanding duties and to achieve personal goals of professional advancement (Mathauer \& Imhoff, 2006) as well as allow them to cope better with the requirements of their job and was found to be especially important for young health professionals (Gray, 2004).

\section{Appreciation}

The study reveals that $89(74.2 \%)$ respondents mentioned been appreciated as one of their motivation factors on working in public health institutions. In the other hand, it may be argued that, appreciation to employees in public health institutions in Morogoro district is conducted and it sound as motivation aspect due to the presence of rewards that act as a check and balance for equity assurance to all staff in order to reduce complaints for the improvement of level of customer satisfaction in health sector. Scholars such as (Drafke \& Kossen, 2002) mentioned appreciation as one of the important aspect of motivation to the health workers. The extent to which appreciation contribute to the provision of better health services delivery could be noted by more than one third of respondents ( 37 respondents) who are motivated by being appreciated. In one of the in depth interview, a respondent pointed out that "I feel happy when am appreaciated because I deal with health of the people". This implies that the employee who feel that they are appreciated by their employers are more motivated than the others and hence their performance is high and make contribution on provision of better health services.

\section{Salary Increment}

Inspite the fact that all respondents $120(100.0 \%)$ responded that they receive increase of salary; Only 40(33.1\%) respondents responded that they are motivated by increase of salary. Nevertheless, low salaries were found to be particularly de-motivating factor as health workers felt that their skills were not valued. Furthermore, they became overworked when taking a second job to supplement their income so as to enable them sustain their needs. Also studies have shown that money has become less important motivator (Sharma, 2003) and Hughes pointed that money itself cannot guarantee productivity among employee, money is still motivator for some employee. It is important that employee link between pay and work performance augur organization achievements.

\section{Membership to the social security fund}

Membership to social security fund is another motivation given to health public workers. It was found that $85(70.8 \%$ ) respondents are motivated by being members of the social security fund. According to regulation of social security fund an employee should be a member on one of the social security fund. This also gives them the opportunity to acquire some loans and to 
have other benefits like maternity, injury and fringe benefits which provided by such funds.

\section{Supervision}

It has found that poor supervision and lack of leadership skills led to de-motivation of the workforce. Skilled managers have the ability to motivate their employees. The results findings show that 91(75.85\%) respondents mentioned supervision as one of the motivation scheme on the public health institutions. Effective managers are also responsible for lobbying on behalf of health workers and without their commitment, factors affecting health worker motivation will not be identified or addressed. Studies indicate the important role of supervision plays as a motivational factor (Manongi et al, 2006) and (Dieleman,Toonen \&Toure, 2003). The results revealed that 54 respondents (58.9\%) are motivated by the kind of supervision prevail.

\section{Recognition}

When an employee accomplishes his/her work to achieve the success of the work, s/he feels to be recognized on his/her work. Recognition is one of the important factors on determining motivation of an employee. In this study it was found that 78(65.0\%) respondents are motivated by being recognized. A part from that the findings from documentary reviews and researcher's informal interviews conducted to the employees supported the results from questionnaire since the findings revealed that recognition is practiced though rarely. Recognition letters are sometimes written to well performed health workers and in most cases it is done verbally. The results indicated further that only 26(33.8\%) respondents respond that they are motivated by being recognized, while only 32(41.6\%) respondents, $7(9.1 \%)$ respondents they perceive recognition with low and demotivation respectively. This is contrary with the findings of previous studies, such as that of (Ramasudi, 2010) who found that health workers agreed or strongly agreed that they receive recognition for tasks well done. Also (Nelson, 2003) pointed out that the need for appreciation for job well done from the employer can be more important than the need for a pay raise for today employees. The employees now want to be recognized and appreciated. This appreciation can be done in various ways such as through positive gesture, positive words and eye contact (Drafke \& Kossen, 2002).

\section{Working condition}

The results findings show 67 (55.8\%) respondents mentioned working condition as one of the motivation factors in public health institutions. Working materials and office maintenance are not in place to most public health centres in Morogoro Municipality. Good physical working including hospital infrastructure and resource availability are important aspect that motivate health workers (Dieleman et al., 2003) and lack of materials was an important de-motivator.

\section{Paid leave}

Annual leave these were the financial incentive paid to health when they applied for the leave. This is much supported by labour laws govern both public and private institutions especially Employment and Labour Relation Act of 2004. The findings showed that all (120(100\%) the 
respondents mentioned leave as one of the financial incentive provided by the government. The findings show that only 25(20.6\%) respondents responded that they are motivated by paid leave received in public institutions while 23(19.1\%) respondents are not motivated. Among the reason mentioned is due to reason that they do not receive paid leave on appropriate time.

\section{Housing allowance}

Only $9(7.5 \%)$ respondents mentioned housing allowance as financial incentives received from their employer. The findings show that very few (3.4\%) respondents responded that they are more motivated by house allowance provided in public institution while $37.3 \%$ of the respondents are not motivated by the housing allowances they received in public institution. Among the reason mentioned is due to reason that their housing allowance is not appropriate with the housing fees charged on the house that is conducive to the health workers.

The low percentage is caused by composition of the respondents. This is not surprising because it was found that this incentive is only paid to medical doctors. This study included both medical doctors as well as other cadres, but the medical doctors working in public institution are very few, that is the number of those who are not doctors outweigh the counterpart.

\section{Promotion}

The findings of this study also revealed that only $8(8.4 \%)$ respondents are very motivated by promotion. More than quarter of the respondents (45 respondents) indicated that they lowly motivated by the promotion provided to health workers. Among the reason mentioned was that, health seldom got promotion at appropriate time. Therefore, promotions do not motivate employee in public health institutions. The key issue in managing promotions is fairness (Brewster, Carey, Dowling, Globbler, Holland \& Warch, 2003). Also (Adebayo, 2006) proved that workplace fairness is positively related to employee motivation. The difficulty with fairness is the process of establishing criteria that serve as basis for promotion procedure. Promotion has been a challenge to human resource management as decision has to be beneficial and fair to both employer and employee (Brewster et al., 2003).

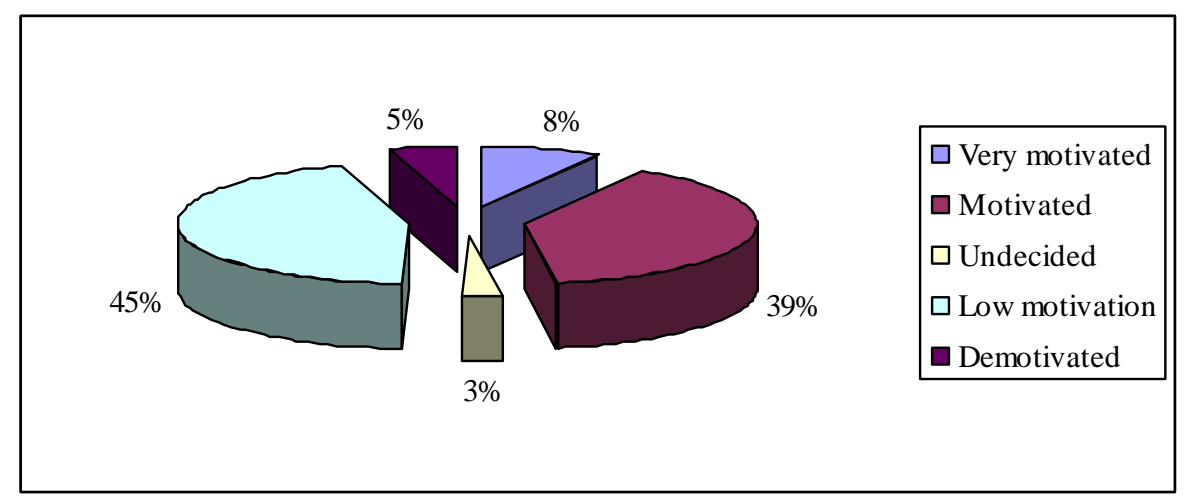

Figure 1. Extent of Promotion 


\subsection{Influence of Motivation on Provision of Customer Care in Public Health Services}

Respondents were asked their opinion on the influence of motivation schemes provided in lowering provision of customer care in public health services. The results findings show that there is significant difference between the employee who are motivated and those who are not motivated with regard to their provision of customer care $(\chi 2=30.66, \mathrm{df}=6 ; \mathrm{p}=0.002)$. (Koontz \& Weihrich, 2007) pointed that managers can motivate their employee through interesting work, and be interesting when it is well designed.

Table 1. Influence of motivation on lowering ability of providing health services

\begin{tabular}{|c|c|c|c|c|c|c|c|c|c|c|}
\hline \multirow{3}{*}{$\begin{array}{l}\text { Influence of } \\
\text { motivation on } \\
\text { lowering provision of } \\
\text { customer care }\end{array}$} & \multicolumn{10}{|c|}{ Level of motivation provided by government } \\
\hline & \multicolumn{2}{|c|}{ very low } & \multicolumn{2}{|c|}{ Low } & \multicolumn{2}{|c|}{ Medium } & \multicolumn{2}{|c|}{ High } & \multicolumn{2}{|c|}{ Total } \\
\hline & $\mathbf{N}$ & $\%$ & $\mathbf{N}$ & $\%$ & $\mathbf{n}$ & $\%$ & $\mathbf{N}$ & $\%$ & $\mathbf{N}$ & $\%$ \\
\hline Very low & 2 & 50.0 & 0 & 0.0 & 1 & 25.0 & 1 & 25.0 & 4 & 3.3 \\
\hline Low & 7 & 29.2 & 7 & 29.2 & 9 & 37.5 & 1 & 4.2 & 24 & 20.0 \\
\hline Medium & 0 & 0.0 & 8 & 28.6 & 18 & 64.3 & 2 & 7.1 & 28 & 23.3 \\
\hline High & 6 & 18.2 & 5 & 15.2 & 20 & 60.6 & 2 & 6.1 & 33 & 27.5 \\
\hline Very high & 10 & 32.3 & 0 & 0.0 & 14 & 45.2 & 7 & 22.6 & 31 & 25.8 \\
\hline Total & 25 & 20.8 & 20 & 16.7 & 62 & 51.7 & 13 & 10.8 & 120 & 100.0 \\
\hline
\end{tabular}

$\chi 2=30.661, \mathrm{df}=12 ; \mathrm{p}=0.002$

\section{Conclusion and Recommendations}

It can be concluded that employee motivation in public health centers is an important aspect in improving provision of health services. Although there are a number of financial and non-financial motivation provided to health workers, but most of public health workers are motivated by being a member on social security fund, medical cover, supervision, and job security. This means that only few employees are not motivated by good number of existing motivation schemes. The results findings show that, more than half of respondents indicated that the rate of influence of motivation on provision of customer care in public health services is high. Hence there is significant difference between the employee who are motivated and those who are not motivated with regard to their provision of customer care.

The suggested strategies for improving motivation of employee to improve customer care include; Improve working condition, Increase salary, Pay housing allowance to all employee, Allowance such as leave, overtime should be paid on time, Promotion should be made on appropriate time and fair, strengthening health systems, especially at ward level is critical for the purpose of attaining the MDGs and human resources desire. High quality care cannot be provided unless issues of de-motivated staff are comprehensively addressed and more information is clearly needed to strengthen the evidence base for effective human resource strategies and policy decisions.

Based on the findings, the following recommendations were made

The management procedure on health system should be revised and should incorporate the aspect of employee motivation for all categories of the people working in health institutions. That means the government should ensure that motivation scheme is not bias and thus 
considers all staff regardless of their positions and age. This can be done by putting the motivation aspects legally so as for the government to be legible in implementing such actions on time and as required.

The study recommends further that employee should be involved in creating evaluation criteria especially for promotion and make it open for all new staff as well as the process should be fair for the health staff to deliver better health services at the maximum level.

The government official should provide allowance at appropriate time. The government here can incorporate the principles of rewards especially that of time, in a sense that rewards or punishment which provided on time can be much beneficial in motivating and remembered to a person respectively.

\section{References}

Adebayo, A. (2006). Motivation for activity-based costing implementation: Administrative and institutional influences, Journal of Accounting \& Organizational Change, 21(1), 42 - 73.

Brewster, C., Carey, L., Dowling, L., Globbler, P., Holland, P., \& Warch, S. (2003). Contemporary Issue in Human resources management: gaining a competitive advantage. Cape Town Oxford University press.

Dieleman, M., Toonen, J., \& Toure, H. (2003). The match between motivation and performance management of health sector workers in Mali. Human Resources for Health, 4(2), 1478-4491.

Drafke, M. W., \& Kossen, S. (2002). The Human side of Organization $8^{\text {th }}$ ed. Upper Saddle River, New Jersey:Prentice Hall.

Elmer, N., De Gilder, D., \& Haslan, S. A. (2004). Motivating Individual and Groups at work: a Social Identity persdpective on leadership and group performance: Academy of management review, 29(3), 459-476.

Gray, R. (2004). How People Work and How you can help them to give their best. Tapei Prentice Hall, Finance Times.

Koontz, A., \& Weihrich, J. (2007). Essentials of Management, London, Pearson Education Prentice Hall.

Leshabari, M. T., Eustace P. Y., Muhondwa, E. P., Naboth, A. A., \& Mbembati, A. A. (2008).Motivation of health care workers in Tanzania: a case study of Muhimbili National Hospital, East African Journal of Public Health, 5(1), 32-37. https://doi.org/10.4314/eajph.v5i1.38974

Manongi R. N., Marchant, T. C., \& Bygbjerg, I. C. (2006). Improving motivation among primary health care workers in Tanzania: a health worker perspective, Human Resources for Health, 4(6).

Mathauer, I., \& Imhoff, I. (2006). Health worker motivation in Africa: the role of non financial incentives and human resource management tools. Human Resources for health 


\section{Macrothink \\ International Journal of Human Resource Studies \\ ISSN 2162-3058 \\ 2018, Vol. 8, No. 2}

4(24), 1478-4491. https://doi.org/10.1186/1478-4491-4-24

Nelson, B. (2003). Top Ten ways to motivate your employee, ABA Bank marketing, 35(10), $56-65$.

Ramasodi, J. M. B. (2010). Factors influencing job satisfaction among healthcare professionals at south rand hospital. Dissertation Submitted in fulfillment of the requirements for the degree of master of public health in the faculty of health systems management and policy (school of public health) at The University of Limpopo.

Sharma, S. (2006). A right way to win an employee, to win his heart, www.bpoindia.org retrieve on Tuesday $13^{\text {th }}$ December 2016

Songstad, N. G., Rekdal, O. B., Massay, D, A. \& Blystad, A. (2011). Perceived unfairness in working conditions: The case of public health services in Tanzania, Health Services Research, 11(34), p. 1-15 http://www.biomedcentral.com/content/pdf/1472-6963-11-34.pdf retrieve on Tuesday $13^{\text {th }}$ December 2016

URT. (2004). Summary Results from Service Delivery Surveys 2003/04(Part I).

URT. (2005). The staff circulars 1996-2005 Dar es Salaam: Tanzania Government Printer.

URT. (2009). Health sector strategic plan III July 2009- June 2015. Dar es Salaam: Ministry of Health and Social Welfare.

URT. (2010). Consultancy Services to Conduct Survey of Public Servants' Service Delivery, President's Office, Public Service Management.

WHO. (2006).The World Health Report 2006: Working together for health Geneva: World Health Organization.

\section{Copyright Disclaimer}

Copyright for this article is retained by the author(s), with first publication rights granted to the journal.

This is an open-access article distributed under the terms and conditions of the Creative Commons Attribution license (http://creativecommons.org/licenses/by/4.0/). 